DOI: $10.15193 /$ zntj/2019/120/295

\author{
ELŻBIETA ROSIAK, DANUTA JAWORSKA
}

\title{
WŁAŚCIWOŚCI PROBIOTYCZNE I PREBIOTYCZNE MIODÓW PSZCZELICH W ASPEKCIE ICH JAKOŚCI I BEZPIECZEŃSTWA ZDROWOTNEGO
}

\begin{abstract}
Streszczenie
Celem pracy był przegląd dostępnej literatury w zakresie właściwości zdrowotnych w tym probiotycznych i prebiotycznych miodów pszczelich. Miód jest jednym z najbardziej zróżnicowanych produktów pod względem składu chemicznego, obejmującym naturalne substancje bioaktywne a także substancje bakteriostatyczne lub antybiotykowe. Odmiany miodu różną się między sobą aktywnością i właściwościami przeciwbakteryjnymi, a miód manuka cechuje się najsilniejszymi właściwościami w tym zakresie. Obecność bakterii kwasu mlekowego w miodzie ma również działanie przeciwbakteryjne. Produktami ich metabolizmu są bakteriocyny i kwasy organiczne w wyniku homo- i heterofermentacji. Mikroflora miodu różni się w zależności od stadium dojrzałości miodu. Miody dojrzewające cechują się głównie obecnością bakterii tlenowych, a grzyby pleśniowe występują w mniejszych ilościach. W dojrzałych miodach najczęściej występują grzyby pleśniowe. Na podstawie obecnego stanu wiedzy można powiedzieć także, że związki fenolowe zawarte w miodzie mają właściwości przeciwutleniające. Oprócz niewątpliwych zalet miodu, należy pamiętać o możliwości zanieczyszczenia miodu zarodnikami Clostridium botulinum.
\end{abstract}

Słowa kluczowe: miody, cechy sensoryczne, właściwości probiotyczne, właściwości prebiotyczne, bezpieczeństwo

\section{Wprowadzenie}

Do produktów pszczelich dostępnych na rynku zalicza się mleczko pszczele, pyłek, pierzgę, wosk pszczeli, jednak najpopularniejszym produktem jest miód. Wyróżnia się miody rodzajowe: kwiatowe, nektarowe powstałe $\mathrm{z}$ nektaru roślinnego oraz miody spadziowe uzyskane głównie z wydalin owadów wysysających żywe części roślin lub wydzielin żywych części roślin (Hemiptera) [19]. Podział na miody odmianowe uwzględnia przewagę pyłku dominującego w miodzie, dlatego miody należą do pro-

Dr inż. E. Rosiak, dr hab. D. Jaworska, Katedra Technologii Gastronomicznej i Higieny Żywności, Wydz. Nauk o Żywieniu Człowieka i Konsumpcji, Szkoła Główna Gospodarstwa Wiejskiego w Warszawie, ul. Nowoursynowska159 C,02-767 Warszawa.Kontakt: elzbieta_rosiak@sggw.pl 
duktów niezwykle zróżnicowanych pod względem składu i właściwości. Warunkowane są one przede wszystkim dobrostanem pszczół, rodzajem surowca, z którego powstał produkt oraz przebiegiem procesu dojrzewania. Najczęściej wymieniane właściwości miodów wynikają z ich działania przeciwdrobnoustrojowego, enzymatycznego i dietetycznego, cech sensorycznych, jak również oddziaływania prebiotycznego oraz obecności bakterii wykazujących działanie probiotyczne. Niektóre szczepy bakterii kwasu mlekowego wykazują korzystne działanie na organizm człowieka polegające na normalizacji mikrobioty przewodu pokarmowego i odpowiedź antyalergiczną organizmu.

\section{Skład miodu a jego właściwości prebiotyczne}

Najliczniejszą grupą związków występujących w miodzie są węglowodany stanowiące ok. $65 \div 87 \%$ (miody nektarowe - ok. $80 \%$, miody spadziowe - ok. $77 \%$ ) wszystkich związków. Spośród monosacharydów wyróżnia się glukozę (ok. 31 \%) oraz fruktozę (ok. $38 \%$ ). Disacharydy stanowią 3,29 $\div 18,60 \%$, w tym sacharoza - średnio $1 \%$ (z reguły jej zawartość nie przekracza $3 \%$, a największą zawartość sacharozy wykazują miody, które nie są w pełni dojrzałe), maltoza $-2,8 \div 7,5 \%$ oraz w znikomych ilościach występują: izomaltoza, maltuloza, melibioza, turanoza, nigeroza, kojibioza, gencjobioza, laminoryboza. Trisacharydy obecne w miodzie to przede wszystkim melecytoza (stanowi $0,33 \div 3,91 \% \mathrm{w}$ zależności od gatunku) oraz w niewielkich ilościach: rafinoza, maltotrioza, fruktomaltoza. Oligosacharydy stanowią ok. $10 \%$ wszystkich cukrów w miodzie i pochodzą głównie z nektaru lub spadzi, zależnie od pochodzenia geograficznego. Dekstryny to wielocukry obecne w miodzie, które stanowią $1 \div 3 \%$ zawartości wszystkich węglowodanów w miodach nektarowych i $5 \div$ $25 \%$ w miodach spadziowych [17].

Znaczna część znanych oligosacharydów miodu wykazuje właściwości prebiotyczne. Ich pozytywne oddziaływanie na organizm polega na selektywnej stymulacji wzrostu pałeczek mlekowych, głównie z rodzaju Lactobacillus i Bifidobacterium, bytujących w przewodzie pokarmowym człowieka. Prebiotyczne właściwości miodu związane z obecnością fruktooligosacharydów (FOS) z najbardziej znaną panozą związane są z aktywnością $\alpha$-D-glukozydazy pszczół. Enzym ten katalizuje transfer grup $\alpha$-D glukopyranozylowych z sacharozy do innych sacharydów. W wyniku tej reakcji powstają fruktooligosacharydy i inne oligosacharydy [6].

Kolejną grupą substancji chemicznych występujących w miodzie pszczelim są kwasy organiczne mające wpływ na smak produktu. Ich przeciętna zawartość wynosi ok. 1,5\% suchej masy, z czego najwięcej, bo aż $70 \div 90 \%$ ogólnej ilości tych związków stanowi kwas glukonowy. Ponadto w miodzie wykryto takie kwasy, jak: mrówkowy, winowy, octowy, szczawiowy, malonowy, kapronowy, kaprylowy, jabłkowy, bursztynowy, mlekowy, cytrynowy, walerianowy [11]. Kwasy organiczne zawarte 
w miodzie pochodzą głównie z organizmów pszczół, przemian zachodzących podczas wytwarzania miodów, a ich ilość wzrasta wraz z postępującym procesem dojrzewania miodu. Ponadto w miodach wykryto niewielkie ilości kwasów nieorganicznych - solnego i fosforowego [11].

Enzymy należą do substancji białkowych obecnych w miodach i pochodzącą głównie z gruczołów pszczół, a w mniejszym stopniu z pyłku kwiatowego oraz spadzi [17]. W miodach występuje głównie diastaza - inaczej zwaną amylazą. Wyróżnia się dwie jej formy: $\alpha$-amylazę, która rozkłada skrobię do dekstryn oraz $\beta$-amylazę, rozkładającą dekstryny do maltozy. Enzym, który katalizuje hydrolizę sacharozy do glukozy i fruktozy oraz uczestniczy w tworzeniu oligosacharydów to inwertaza - inaczej zwana $\beta$-fruktofuranozydazą lub sacharazą. W miodach występuje naturalnie również katalaza - enzym rozkładający nadtlenek wodoru, a tym samym zmniejszający wartość inhibinową miodu oraz oksydaza glukozowa - enzym utleniający glukozę oraz wpływający na zawartość kwasu glukonowego w miodzie. W miodach występuje także peroksydaza, która katalizuje reakcje utleniania różnych związków nadtlenkiem wodoru [17].

Niewielka zawartość witamin w miodzie sprawia, że nie stanowi on istotnego źródła tych składników w diecie człowieka. Wśród witamin wykrytych w omawianym produkcie wymieniane są: $\mathrm{B}_{1}$ (tiamina), $\mathrm{B}_{2}$ (ryboflawina), PP (kwas nikotynowy), $\mathrm{B}_{6}$ (pirydoksyna), $\mathrm{B}_{5}$ (kwas pantotenowy), $\mathrm{H}$ (biotyna), $\mathrm{B}_{9}$ (kwas foliowy), witamina $\mathrm{C}$ oraz filochinon (witamina $\mathrm{K}$ ), a także śladowe ilości witamin A i D [1].

Przeciętna zawartość związków mineralnych w miodach wynosi $0,02 \div 1,03 \%$. Do pierwiastków wykrytych w miodach należą: potas, krzem, sód, żelazo, miedź, magnez, mangan, siarka, nikiel, fosfor, chlor, kobalt, jod, cynk, pallad, arsen, stront, glin, wolfram, ołów, chrom, tytan, bar, molibden, wanad, cyna, srebro. Ilość składników mineralnych w miodzie zależy przede wszystkim od jego rodzaju i odmiany: miody nektarowe zawierają $0,05 \div 0,50 \%$ składników mineralnych, miody nektarowospadziowe $-0,32 \div 0,52 \%$, a miody spadziowe najwięcej - ok. $1 \%$ składników mineralnych [1].

Miody zawierają również niewielkie ilości substancji wykazujących działanie hormonalne. Mogą one pochodzić z organizmów pszczół, a są nimi acetylocholina, cholina lub z roślin - hormon wzrostu. Zawartość acetylocholiny w miodzie wynosi ok. $5 \mu \mathrm{g} / \mathrm{g}$ miodu [17].

\section{Jakość sensoryczna miodów}

Na smak i aromat miodu wpływa ok. 50 związków aromatycznych (olejków eterycznych), które pochodzą przede wszystkim z nektaru. Są to lotne substancje, dlatego też ich zawartość maleje podczas ogrzewania i długiego przechowywania. Do związków tych zaliczane są: aldehydy i ketony (aldehydy: mrówkowy, octowy i izomasłowy oraz aceton, diacetyl), związki polifenolowe, estry, wyższe alkohole alifatyczne. Wy- 
kazano jednak, że wpływ na smak i aromat słodkiego produktu mają także: kwasy organiczne, aminokwasy, cukry, garbniki, woski, 5-hydroksymetylofurfural - w sumie $100 \div 120$ substancji $[11,30]$.

Barwa miodów zależy od zawartości w nich różnych grup barwników. Dotychczas przeprowadzono mało badań nad zawartością tych substancji w miodach. Wykazano jednak obecność karotenoidów (karotenu i ksantofilu), flawonoidów (także związków powstałych przez ich połączenie), chlorofili oraz antocyjanów. Ponadto na barwę miodu mają wpływ również miodowe koloidy, związki powstałe w wyniku połączenia polifenoli i tanin oraz melanoidy (produkty reakcji cukrów z aminokwasami) $[11,17,30]$.

W składzie chemicznym miodu pszczelego wyróżnia się również niewielkie ilości związków azotowych. Zawartość białek w miodach waha się w przedziale $0,25 \div 3 \%$ [19]. Wśród obecnych białek występują albuminy, globuliny, peptony oraz nukleoproteidy. Większą zawartością związków azotowych w porównaniu z innymi odmianami miodów charakteryzuje się miód wrzosowy [17].

Pozostałe substancje obecne w miodzie nazywane są domieszkami. Ich zawartość wynosi nie więcej niż $1 \%$. Wśród nich wyróżnia się: pyłek kwiatowy (ok. 3000 ziaren pyłku w $1 \mathrm{~g}$ miodu), mleczko pszczele $(0,0001 \%)$, kwasy tłuszczowe (np. kwas arachidonowy), sterole i fosfolipidy $[11,17]$.

Przedstawiona gama związków powoduje, że miody cechują się unikatową jakością sensoryczną w zakresie zapachu, konsystencji oraz cech smakowych. Wyniki badań własnych dotyczące porównania jakości sensorycznej rynkowych miodów lipowych wskazują, że miody jednogatunkowe mogą różnić się indywidualnie między sobą w zakresie intensywności cech opisujących ich profil sensoryczny (rys. 1).

Jak wynika z badań własnych, próbki wykazywały istotne zróżnicowanie w odniesieniu do ocenianych cech jakościowych, takich jak: jakość ogólna, barwa, gęstość, zapach słodki, miodowy, smak cierpki, miodowy i wyróżnik określany jako „inny”. Przeprowadzona ocena wykazała znaczne różnice w obrębie tej samej odmiany. Brak różnic stwierdzono jedynie w przypadku intensywności smaku słodkiego. Najwyższy niekorzystny wpływ na jakość ogólną miodów stwierdzono w przypadku odczucia cierpkości miodów $(\mathrm{r}=-0,948)$. 


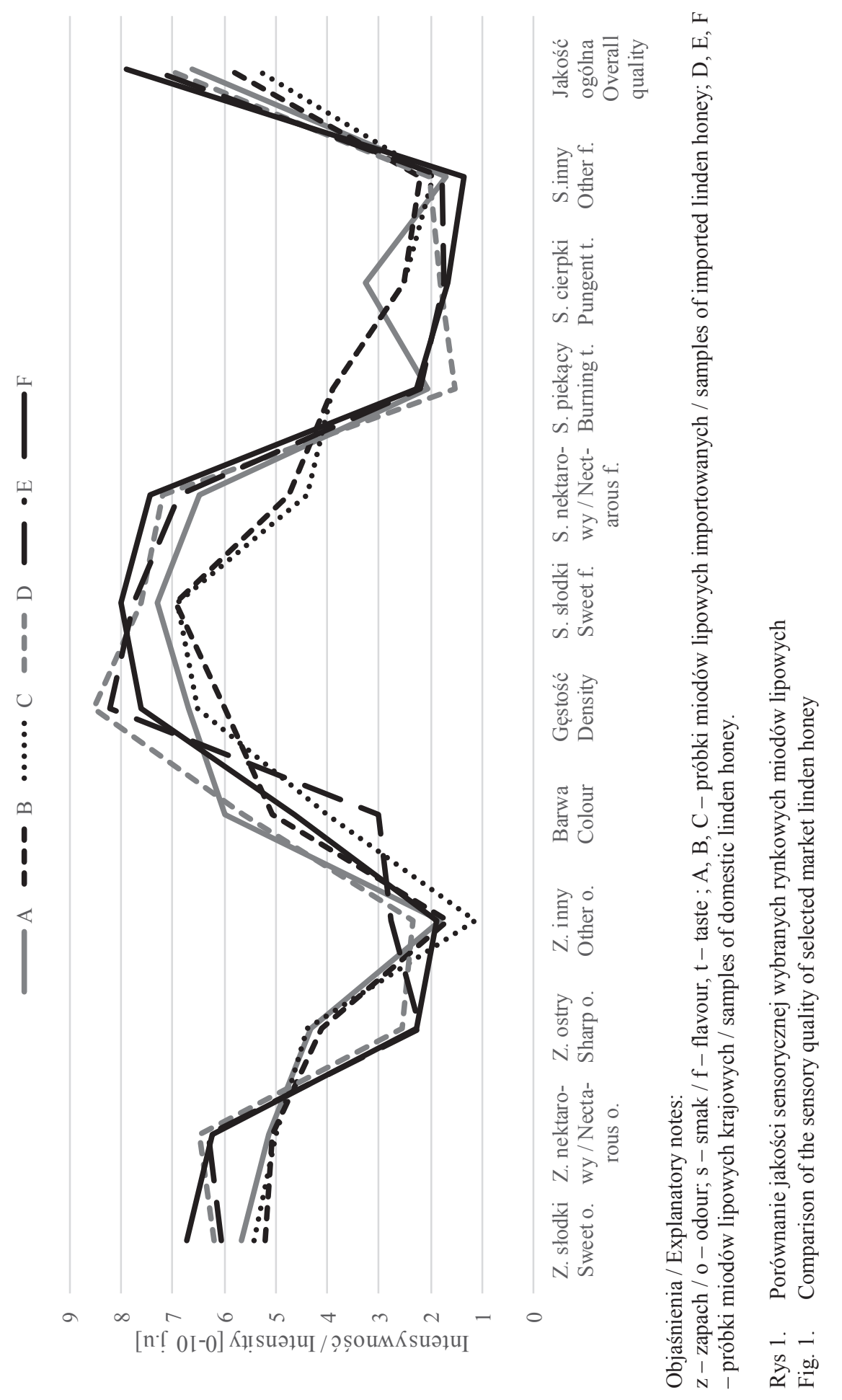




\section{Wlaściwości prozdrowotne miodu}

Najważniejszą cechą miodu jest jego właściwość antybakteryjna wykazywana wobec różnych mikroorganizmów, w tym również patogennych. Poszczególne odmiany miodu charakteryzują się różną aktywnością w tym zakresie. Zawartość związków o charakterze antybiotycznym zależy od wielu czynników: pochodzenia botanicznego miodu, czynników środowiskowych i klimatycznych, a także przebiegu procesu pozyskiwania miodów $[8,28,30]$. Działanie hamujące rozwój drobnoustrojów przez miód jest uwarunkowane obecnością również inhibiny - nadtlenku wodoru, będącego produktem reakcji utleniania glukozy. Innymi związkami zaliczanymi do tej grupy są: tymol, $\alpha$-bisfenol, garbniki katechinowe, lizozym, cyneol, kanifen, kwas benzoesowy, związki flawonoidowe [17].

Według danych literaturowych najsilniejsze właściwości przeciwdrobnoustrojowe wykazuje nowozelandzki miód Manuka [4, 24]. Przeciwbakteryjne właściwości miodu związane są z: wysokim ciśnieniem osmotycznym (wynikającym z dużego stężenia cukrów), występowaniem w jego składzie kwasów organicznych, które wpływają między innymi na obniżenie pH produktu, obecnością enzymu oksydazy glukozy, która sama nie ma właściwości antybakteryjnych, ale przez utlenianie glukozy powoduje powstawanie nadtlenku wodoru (inhibiny) oraz z obecnością wielu substancji antybiotycznych, pochodzących z wydzielin pszczół (np. lizozymu) oraz ze spadzi i nektaru. Znacznie większą aktywnością antybiotyczną charakteryzują się wyciągi z miodu (np. alkoholowe) i jego wodne roztwory, gdyż rozcieńczenie przyspiesza reakcję powstawania bakteriobójczego nadtlenku wodoru [9].

Na rys. 2. przedstawiono wpływ wybranych miodów na trzy szczepy Staphylococcus aureus (ATCC 23925, 4.4, 2319). Analizy wykonano metodą dyfuzyjnokrążkową. Zahamowanie wzrostu bakterii przez miód mierzono jako strefę zahamowania wzrostu wokół krążka [mm]. Największą strefę zahamowania wzrostu trzech badanych szczepów $S$. aureus stwierdzono w przypadku miodu Manuka, który najsilniej oddziaływał na szczep $S$. aureus 2319. Miody krajowe wykazywały równie silne oddziaływanie jak miody importowane. Silne działanie antybakteryjne stwierdzono w przypadku miodu mniszkowego, wielokwiatowego z Meksyku i lawendowego.

Innym wymienianym mechanizmem działania antybakteryjnego miodu jest obecność w nim bakterii kwasu mlekowego (Lactic Acid Bacteria, LAB). Produktami ich metabolizmu są bakteriocyny oraz kwasy organiczne jako wynik homo- i heterofermentacji. Bakteriocyny są białkami lub kompleksami białkowymi wykazującymi aktywność inhibitującą w stosunku do bakterii Gram-dodatnich i Gram-ujemnych [3]. Inne produkowane przez LAB związki wykazujące działanie bioaktywne to wolne kwasy tłuszczowe, etanol, benzoesan, enzymy, peptydy, antybiotyki $[3,14,15]$. 


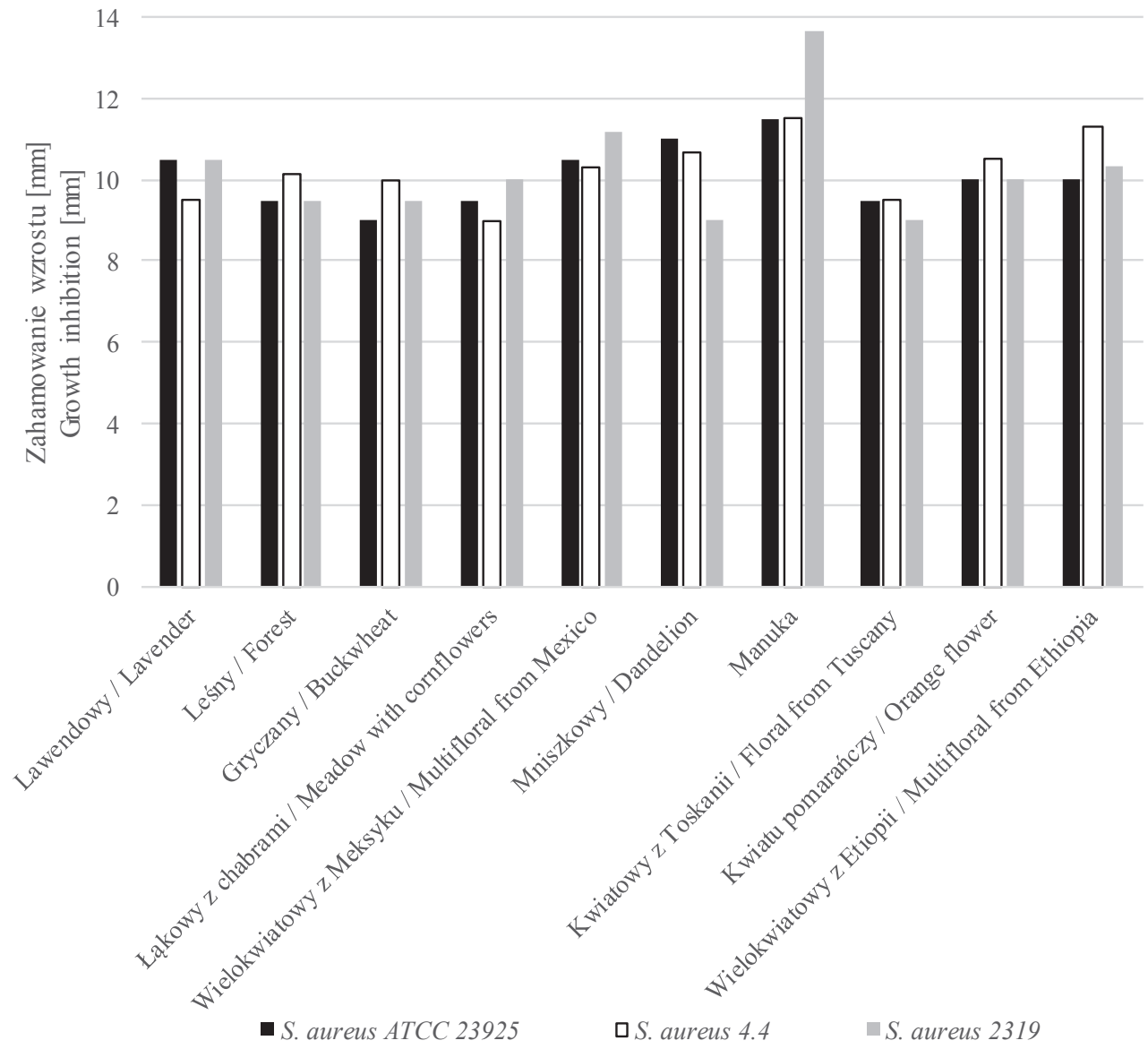

Rys 2. Zahamowanie wzrostu trzech szczepów Staphylococcus aureus przez wybrane miody

Fig. 2. Inhibition of growth of three Staphylococcus aureus strains by selected honeys

W badaniach nad wpływem miodu wielokwiatowego na wzrost Escherichia coli, w doświadczeniu in vivo na szczurach, Shamala i wsp. [23] wykazali, że po $120 \mathrm{~h}$ od doustnego podania bakterii ich rozwój został skutecznie zahamowany. Wybrane miody dzięki swoim właściwościom antybakteryjnym przyczyniają się zatem do ochrony przed zakażeniami [11]. Wykazano ponadto, że miód hamuje rozwój bakterii Helicobacter pylori [18], które są głównym czynnikiem odpowiedzialnym za powstawanie wrzodów żołądka.

Miody cechują się również silnymi właściwościami przeciwutleniającymi. Jedną z ważniejszych funkcji żywności jest zapewnienie odpowiedniej podaży związków o charakterze przeciwutleniającym, które neutralizując wolne rodniki, wspomagają zachowanie przeciwutleniającej bariery ochronnej ustroju człowieka. Do związków tych 
należy zaliczyć przede wszystkim karotenoidy, polifenole, tokoferole i kwas askorbinowy $[8,32]$. Powszechność występowania związków fenolowych w świecie roślinnym oraz ich rola i znaczenie w ochronie przeciwutleniającej organizmu człowieka skłoniła naukowców do podjęcia szczegółowych badań na ten temat [13].

Ze względu na właściwości przeciwutleniające związki fenolowe wykazują zdolność regulowania stężenia glukozy i cholesterolu we krwi, dlatego ich spożywanie jest zalecane osobom chorym na cukrzycę. Fenolokwasy mają także inne działania farmakologiczne: żółciopędne (np. kwasy: kawowy, ferulowy i chlorogenowy), przeciwbakteryjne (kwasy: kawowy, wanilinowy, p-kumarowy), hemostatyczne (kwas elagowy) oraz antyseptyczne, ściągające i przeciwpotne (kwas galusowy). Kwasy fenolowe, dzięki właściwościom przeciwutleniającym, zapobiegają również degradacji kolagenu, przez co przeciwdziałają fotooksydatywnym uszkodzeniom skóry [22].

Wilczyńska [30] podaje, że ogólna zawartość polifenoli w krajowych miodach świeżych wahała się w granicach od ok. $35 \mathrm{mg}$ GAE/100 g w miodach rzepakowych do prawie $150 \mathrm{mg}$ GAE/100 $\mathrm{g} \mathrm{w}$ miodach wrzosowych. Podczas przechowywania ogólna zawartość polifenoli znacznie wzrosła we wszystkich analizowanych próbkach i wynosiła średnio $57 \div 200 \mathrm{mg}$ GAE/100 g. Autorka wykazała, że pod względem aktywności przeciwutleniającej największą skutecznością neutralizowania wolnych rodników charakteryzowały się miody wrzosowe, których skuteczność sięgała 84 \%. Aktywnością przeciwutleniającą przekraczającą $60 \%$ cechowały się próbki miodów lipowych i spadziowych.

W badaniach miodów konwencjonalnych Świetlikowska i wsp. [26] wykazali, że charakteryzowały się one istotnie większą zawartością sumy kwasów fenolowych, a ponadto były także istotnie zasobniejsze w rutynę i D-glikozyd kemferolu (z grupy flawonoidów) w porównaniu z miodami uznanymi za ekologiczne. Natomiast miody określane jako ekologiczne odznaczały się istotnie większą zawartością sumy flawonoidów (w tym luteoliny) w porównaniu z miodami konwencjonalnymi. Wykazano ponadto, że większą zawartością polifenoli oraz aktywnością przeciwutleniającą charakteryzują się miody ciemne - gryczane, wrzosowe oraz spadziowe [30]. Na podstawie istniejącego stanu wiedzy można więc stwierdzić, że związki fenolowe zawarte w miodach mogą wzmacniać naturalne mechanizmy obrony przed szokiem tlenowym i chemicznym. Do flawonoidów wykrytych w miodzie, wspomagających działanie antybiotyczne, należą m.in.: apigenina, kemferol, kwercetyna, hesperydyna, pinocembryna, galangina [9].

\section{Jakość mikrobiologiczna miodu a właściwości probiotyczne}

Mikroflora miodu dojrzewającego różni się od mikroflory miodu dojrzałego. Wynika to przede wszystkim $\mathrm{z}$ malejącej ilości wody w czasie dojrzewania miodu. $\mathrm{W}$ miodach dojrzewających $\mathrm{w}$ przewadze znajdują się bakterie tlenowe pochodzące 
w $70 \div 75 \%$ z przewodu pokarmowego pszczól, natomiast grzyby pleśniowe i drożdżoidalne (Saccharomyces i Torulopsis) znajdują się w mniejszości [11]. W dojrzałych miodach najczęściej występują grzyby oraz w niewielkich ilościach przetrwalniki bakterii tlenowych i beztlenowych. W miodach spadziowych dominują grzyby pleśniowe, natomiast w nektarowych - grzyby drożdżoidalne.

Do Gram-dodatniej, fakultatywnie beztlenowej mikroflory komensalnej występującej powszechnie na kwiatach i w przewodzie pokarmowym wielu zwierząt i ludzi zalicza się bakterie kwasu mlekowego wykazujące działanie probiotyczne, polegające na ochronie przed patogenami bakteryjnymi $[7,16,28]$.

W 2008 roku Olofsson i Vasquez [15] dokonali identyfikacji mikrobiomu żołądka pszczół Apis mellifera na podstawie genu 16S rRNA rodzaju Lactobacillus. W analizie filofenetycznej mikrobiomu żołądka pszczół wykazali, że mikroflora składa się z 10 różnych filotypów. Pięć z nich jest blisko spokrewnionych z pierwotnie opisanymi Lactobacillus kunkeei, Bifidobacterium asteroides i Bifidobacterium coryneforme. Kolejne pięć filotypów określono jako najbardziej zbliżone do rodzaju Lactobacillus. Trzy z wymienionych 10 filotypów znaleziono w świeżym miodzie. Lactobacillus kunkeei występował $\mathrm{w}$ największej liczbie $5 \times 10^{5} \mathrm{jtk} / \mathrm{g}$ miodu podczas zbioru przez pszczoły nektaru z kwiatów malin. Żadnego z tych 3 filotypów wymienieni autorzy nie wykazali w miodzie z kwiatów malin przechowywanym przez 2 miesiące ani jako żywy izolat, ani pozostałość DNA. Pozostałość DNA z jednego szczepu stwierdzono w miodzie lipowym przechowywanym przez 12 miesięcy. Z kolei Asama i wsp. [2] w 2015 r. stwierdzili, że flora bakteryjna żołądka pszczół jest zdominowana przez rodzaj Gluconobacter (średnio 64,7 \%). Bakterie kwasu mlekowego z rodzaju Lacobacillus stanowiły średnio $22,0 \%$, z czego ponad połowa to Lactobacillus kunkeei (57 \%), a 28,3 \% mikroflory należy do Lactobacillus insectis. Wśród mikroflory przewodu pokarmowego pszczół rodzaj Lactobacillus stanowił 34,6 \%, a Bifidobacterium - 21 \%. Dominującym gatunkiem LAB przewodu pokarmowego pszczół jest Lactobacilus insectis $(60,1 \%)$, drugim najliczniej reprezentowanym gatunkiem jest Lactobacillus kefiranofaciens, natomiast Lactobacillus kunkeei występował w bardzo małej liczbie (0,6 \%). Analiza obecności sekwencji genu 16S rRNA bakterii z rodzaju Lactobacillus w produktach pszczelich umożliwiła określenie obecności tych bakterii na poziomie odpowiednio: w miodzie - 90,9\%; w pyłku - 70,6 \% i w pierzdze $-83,9 \%$. W produktach pszczelich Lactobacillus kunkeei był dominującym gatunkiem - powyżej $98 \%$ [2]. Dowiedziono także, że izolat Lactobacillus kunkeei YB38 wspomagał produkcję przeciwciał IgA u ludzi. W badaniach in vitro wykazano, że szczepy YB83 oraz YB38 występujące w pyłku pszczelim zwiększały produkcję przeciwciał IgA w komórkach pęczków Peyera u myszy i przejawiały niewielką aktywność mitogenną. W zależności od gatunku i szczepu Lactobacillus działanie immunomodulacyjne może być różne 
i szczepy te mogą bezpiecznie poprawić reakcję immunologiczną organizmu człowieka [2].

Zauważono wzajemną zależność pomiędzy obecnością bakterii kwasu mlekowego w przewodzie pokarmowym pszczół i produktami pszczelimi, które mogą być uznane za żywność fermentowaną $[15,28]$. Bakterie LAB znalazły niszę w żołądku pszczół z dostatkiem składników, a w zamian zapewniły owadom ochronę przed szkodliwymi mikroorganizmami. Te odkrycia pozwalają lepiej zrozumieć zagadnienia związane z dobrostanem pszczół, produkcją i przechowywaniem miodu oraz aspektami wpływu bakterii probiotycznych na zdrowie człowieka [7]. Bakterie kwasu mlekowego wykazują działanie probiotyczne u ludzi i owadów polegające na ochronie przed patogenami bakteryjnymi [7, 28]. Planowano wprowadzenie na polski rynek w 2018 roku preparatów probiotycznych ( $\mathrm{Nr}$ zgłoszenia P.423363) dla pszczół, zawierających 12 wyselekcjonowanych szczepów Lactobacillus kunkeei i 2 szczepy Fructobacillus fructosus. Opracowane preparaty probiotyczne wykazują dużą skuteczność w zapobieganiu i zwalczaniu zakażeń grzybami (Nosema apis, Nosema ceranae) i bakteriami patogennymi (Paenibacillus larvae, Escherichia coli, Raoultella ornithinolytica, Klebsiella pneumoniae), powodując zwiększenie odporności i kondycji pszczół oraz wydłużenie ich życia $[16,18]$.

\section{Jakość mikrobiologiczna miodu a zagrożenia zdrowotne}

Należy zauważyć, że miody mogą stanowić również poważne zagrożenie zdrowotne wynikające z obecności przetrwalników Clostridium botulinum. Według Wojtackiej i wsp. [31] miód zanieczyszczony przetrwalnikami C. botulinum jest jedną z przyczyn botulizmu dzieci do 1. roku życia. W Europie opisano zakażenia niemowląt miodem zanieczyszczonym przetrwalnikami C. botulinum, m.in. w Portugalii, Hiszpanii i we Francji $[10,12,20]$. Niepublikowanie takich doniesień w Polsce może wynikać z braku danych lub nieprawidłowej diagnostyki, ponieważ botulizm niemowląt może być mylony z syndromem nagłej śmierci niemowląt [5].

Częstotliwość występowania przetrwalników laseczek beztlenowych C. botulinum w miodzie w dużym stopniu zależy od kraju, z którego pochodzi, a także od regionu geograficznego tego kraju. Wykazano, że najbardziej zanieczyszczony przetrwalnikami C. botulinum jest miód z Chin i Argentyny (odpowiednio: 12 i 20 \% prób pozytywnych). Obecność przetrwalników stwierdzono w $23 \%$ próbek ze sprzedaży bezpośredniej i w $5 \%$ próbek ze sprzedaży detalicznej, a próby pozytywne wskazywały na obecność $4 \div 60$ przetrwalników/g miodu. Ze względu na właściwości fizykochemiczne miodu, tzn. niskie pH oraz wysokie stężenie cukrów, nie jest on produktem, w którym mogą kiełkować przetrwalniki $C$. botulinum. Wprowadzone wraz z miodem do przewodu pokarmowego człowieka dorosłego nie kiełkują, nie wytwarzają toksyn i opuszczają jego organizm wraz z kałem, nie wywołując intoksykacji ani innej szkody 
dla organizmu, jednak w przypadku niedojrzałego przewodu pokarmowego niemowląt i małych dzieci przetrwalniki znajdują sprzyjające warunki do kiełkowania i wytwarzania neurotoksyny [25].

\section{Podsumowanie}

Z przedstawionego przeglądu literatury wynika, że pod względem chemicznym miód stanowi jedną z najbardziej zróżnicowanych substancji. Występują w nim naturalne substancje bioaktywne, bakteriostatyczne czy antybiotyczne. Poszczególne odmiany miodu charakteryzują się różną aktywnością antybakteryjną. Duże znaczenie dla właściwości przeciwdrobnoustrojowych miodu ma obecność w nim bakterii kwasu mlekowego (LAB) Lactobacillus i Bifidobacterium, głównie ze względu na produkcję bakteriocyn, kwasu mlekowego i octowego a także etanolu, benzoesanu, enzymów. Lactobacillus kunkeei jest dominującym gatunkiem w produktach pszczelich, a niektóre jego szczepy wykazują probiotyczne działanie na organizm człowieka. Należy zauważyć, że oligosacharydy pełniące rolę prebiotyczną stanowią ok. $10 \%$ wszystkich cukrów w miodzie. Poza niekwestionowanymi zaletami miodów należy pamiętać o możliwości ich zanieczyszczenia przetrwalnikami Clostridium botulinum.

\section{Literatura}

[1] Alvarez-Suarez J., Tulipani S., Romandini S., Bertoli E., Battino M.: Contribution of honey in nutrition and human health: A review. Mediterranean J. Nutr. Metabol., 2010, 3, 15-23.

[2] Asama T., Arima T.-H., Gomi T., Keishi T., Tani H., Kimura Y., Tatefuji T., Hashimoto K.: Lactobacillus kunkeei YB38 from honeybee products enhances IgA production in healthly adults. J. Appl. Microbiol., 2015, 119, 818-826.

[3] Aween M.M., Hassan Z., Muhialdin B.J., Noor H.M., Eljamel Y.A.: Evaluation of antibacterial activity of Lactobacillus acidophilus strains isolated from honey. Am. J. Appl. Sci., 2012, 9 (6), $807-$ 817.

[4] Bogdanow S.: Nature and origin of the antibacterial substances in honey. Lebens.-Wiss. U.-Technol, 1997, 30, 748-753.

[5] Böhnel H., Behrens S., Loch P., Lube K., Gessler F.: Is there a link between infant botulism and sudden infant death? Bacteriological results obtained in Central Germany. Eur. J. Pediatr., 2001, $160,623-628$.

[6] Borawska J., Bednarski W., Gołębiewska J.: Charakterystyka sacharydów miodu oraz możliwości zastosowania Bifidobacterium do modyfikacji ich składu i właściwości. Żywność. Nauka. Technologia. Jakość, 2011, 3 (76), 29-39.

[7] Forsgren E., Olofsson T.C., Vásquez A., Fries I.: Novel lactic acid bacteria inhibiting Paenibacillus larvae in honey bee larvae. Apidologie, 2010, 41, 99-108.

[8] Gheldof N., Wang X.H., Engeseth N.J.: Identification and ąuantification of antioxidant components of honeys from various floral sources. J. Agric. Food Chem., 2002, 50, 5870-5877.

[9] Hegazi A., El-Moez S., Abdou A., Allah F.: Antibacterial activity of some types of monofloral honey against Clostridium acetobutylicum and Clostridium perfringens. Int. J. Current Microb. Appl. Sci., 2014, 3 (9), 552-565. 
[10] Hoarau G., Pelloux I., Gayot A., Wroblewski I., Popoff M.R., Mazuet C., Maurin M., Croizé J.: Two cases of type a infant botulism in Grenoble, France: No honey for infants. Eur. J. Pediatr., 2012, 171, 589-591.

[11] Kędzia B., Hołderna-Kędzia E.: Miód. Skład i właściwości biologiczne. Przeds. Wyd. Rzeczpospolita, Warszawa 2008.

[12] López-Laso E., Roncero-Sánchez-Cano I., Arce-Portillo E., Ley-Martos M., Aguirre-Rodríguez J., García-Ron A., Mora-Navarro D., Méndez-García M., Camino-León R.: Infant botulism in Andalusia (Southern Spain). Eur. J. Pediatr. Neurol., 2014, 18 (3), 321-326.

[13] Miranda C.L., Stevens J.F., Ivanow V., McCall M., Frei B., Deinzer M.L., Buhler D.R.: Antioxidant and prooxidant actions of prenylated and nonprenylated chalcones and flavanones in vitro. J. Agric. Food Chem., 2000, 48(9), 3876-3884.

[14] Olofsson T.C., Butler E., Markowicz P., Lindholm Ch., Larsson L., Vasquez A.: Lactic acid bacterial symbionts in honeybees - an unknown key to honey's antimicrobial and therapeutic activities. Int. Wound J., 2014, 13(5), 668-679.

[15] Olofsson T.C., Vásquez A.: Detection and identification of novel lactic acid bacterial flora within honey stomach of the honeybee Apis melifera. Curr. Microbiol., 2008, 57, 356-363.

[16] Pachla A., Wicha M., Ptaszyńska A.A., Borsuk G., Łaniewska-Trokenheim Ł., Małek W.: The molecular and phenotypic characterization of fructophilic lactic acid bacteria isolated from the guts of Apis mellifera L. derived from a Polish apiary. J. Appl. Genet., 2018, 59(4), 503-514.

[17] Popek S.: Studium identyfikacji miodów odmianowych i metodologii oceny właściwości fizykochemicznych determinujących ich jakość. Wyd. AE. w Krakowie, Kraków 2001.

[18] Ptaszyńska A.A., Małek W., Borsuk G., Grzęda M., Wicha M., Pachla A.: Szczepy bakterii z rodzajów Lactobacillus i Fructobacillus wyizolowane z przewodu pokarmowego pszczół miodnych do zastosowania w zwalczaniu i zapobieganiu chorób pszczół oraz preparaty probiotyczne na bazie takich szczepów bakterii. Nr zgłoszenia P.423363. 06.11.2017.

[19] Rozporządzenie Ministra Rolnictwa i Rozwoju Wsi z dnia 29 maja 2015 r. zmieniające rozporządzenie w sprawie szczegółowych wymagań w zakresie jakości handlowej miodu. Dz. U. 2015 r., poz. 850 .

[20] Saraiva M., Campos Cunha I., Costa Bonito C., Pena C., Toscano M., Teixeira Lopes T., Sousa I., Calhau A.: First case of infant botulism in Portugal. Food Control, 2012, 26, 79-80.

[21] Sato T.: The nutraceutical benefit: Honey. Nutrition, 2000, 16, 468-469.

[22] Schramm D.D., Karim M., Schrader H.R., Holt R.R., Cardetti M., Keen C.L.: Honey with high levels of antioxidants can provide protection to healthy human subjects. J. Agric. Food Chem., 2003, $51,1732-1735$.

[23] Shamala T.R., Shri Jyothi Y.P., Saibaba P.: Antibacterial effect of honey on the in vitro and in vivo growth of Escherichia coli. World J. Microbiol. Biotechnol., 2002, 18 (9), 863-865.

[24] Snow M.J., Manley-Harris M.: On the nature of non-peroxide antibacterial activity in New Zealand Manuka honey. Food Chem., 2004, 84, 145-147.

[25] Sobel J.: Botulism. Clin. Infect. Dis., 2005, 41, 1167-1173.

[26] Świetlikowska K., Hallmann E., Dłogołęcka K., Rembiałkowska E.: Ocena wartości odżywczej i sensorycznej wybranych miodów pochodzących z produkcji ekologicznej i konwencjonalnej. J. Res. Appl. Agric. Eng., 2011, 56 (4), 161-164.

[27] Turkmen N., Sari F., Poyrazoglu E.S., Velioglu S:. Effects of prolonged heating on antioxidant activity and colour of honey. Food Chem., 2006, 95, 653-657.

[28] Vásquez A., Forsgren E., Fries I., Paxton R.J., Flaberg E., Szekely L., Olofsson T.C.: Symbionts as major modulators of insect health: Lactic acid bacteria and honeybees. Plos One, 2012, 7(7), \#e33188. DOI: 10.1371/journal.pone.0033188. 
[29] Vela L., de Lorenzo C., Perez R.A.: Antioxidant capacity of Spanish honeys and its correlation with polyphenol content and other physicochemical properties. J. Sci. Food Agric, 2007, 87, 1069-1075.

[30] Wilczyńska A.: Jakość miodów w aspekcie czynników wpływających na ich właściwości przeciwutleniające. Rozprawa habilitacyjna. Akademia Morska w Gdyni, Gdynia 2012.

[31] Wojtacka J., Gomółka-Pawlicka M., Liedtke K., Uradziński J.: Jakość i higiena miodu. Med. Weter., 2014, 70 (12), 719-724.

[32] Zujko M., Witkowska A., Łapińska A.: Właściwości antyoksydacyjne miodów pszczelich. Brom. Chem. Toksyk., 2005, 38 (1), 7-11.

\section{PROBIOTIC AND PREBIOTIC PROPERTIES OF BEE HONEYS IN TERMS OF THEIR QUALITY AND HEALTH SAFETY}

\section{S u m m a r y}

The objective of the research study was to review the available reference literature for health benefits of bee honeys including their probiotic and prebiotic properties. Honey is one of the most diverse products in terms of its chemical composition, which includes natural bioactive substances as well as bacteriostatic or antibiotic substances. Honey varieties differ in their activity and antibacterial properties, and Manuka honey is characterized by the strongest properties in this respect. The presence of lactic acid bacteria in honey has also an antibacterial effect. The products of their metabolism are bacteriocins and organic acids as a result of homo- and hetero-fermentation. The honey microflora varies depending on the stage of honey maturity. Honeys during maturation are mainly characterized by the presence of aerobic bacteria, and moulds occur in smaller amounts. In the ripe honeys moulds most often occur. On the basis of the current state of knowledge it can also be said that the phenolic compounds contained in honey have antioxidant properties. In addition to the unquestionable advantages of honey it should be remembered that honey might be contaminated with Clostridium botulinum spores.

Key words: honey, sensory features, probiotic properties, prebiotic properties, safety 